\title{
ヒト声帯黄斑結合組織の線維構造
}

\author{
山下 耕太郎*，石 井 甲 介**，佃
}

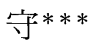

\section{Ultrastructure of the Macula Flava of Human Vocal Fold}

\author{
Kotaro Yamashita, M.D., ${ }^{*}$ Kosuke Ishii, M.D., ${ }^{* *}$ and Mamoru Tsukuda, M.D. ${ }^{* * *}$ \\ *Department of Otorhinolaryngology, Yokohama Senin Hoken Hospital, Yokahama, \\ **Department of Otorhinolaryngology, Saitama Medical Center, Saitama Medical \\ School, Saitama, and ${ }^{* * *}$ Department of Otorhinolaryngology, \\ Yokahama City University School of Medicine, Yokohama
}

The anterior and posterior macula flava are located at the anterior and posterior ends of the vocal folds. The macula flava have a peculiar structure with dense elastic fibers, but their functions are unknown.

The physiologic properties of the macula flava are thought to be determined by the alignment and distribution of collagen and elastic fibers.

We studied the three dimensional arrangement of collagen and elastic fibers in the macula flave of the human vocal fold by scanning electron microscopy after dissolving the cellular elements and the collagen fibers with a $90 \%$ formic acid treatment and, also, digesting the cellular elements and the elastic fibers with a $10 \%$ sodium hydroxide treatment.

This study revealed that the anterior macula flava consists of lumps of fine collagen fibers and fine elastic fibers, detached from the thyroid cartilage, whereas the posterior macula flava consists of thick bundles of collagen and elastic fibers running longitudinally and connecting directly to the arytenoid cartilage.

It was speculated that the anterior macula flava have a massive mixed structure composed of collagen fibers and elastic fibers which run separately in the vocal ligamentum, to form the fulcrum apart from the thyroid cartilage.

Furthermore, the posterior macula flava have a structure corresponding to the longitudinal strong force.

Key words : 声带, 黄斑, 膠原線維, 弾性線維

\section{I . 緒 言}

声带粘膜下固有層の前・後端に位置する前黄

*横浜船員保険病院耳鼻咽喉科, **埼玉医科大学総合 医療センター耳鼻咽喉科, ${ }^{* * *}$ 横浜市立大学医学部耳 鼻咽喉科

別刷請求： $\mathbf{T} 240$ 横浜市保土ヶ谷区釜台町 137 横浜船員保険病院耳鼻咽喉科 山下耕太郎 投稿受付：1996年 9 月12日
斑および後黄斑は，ともに弾性線維の豊富な特 異な構造をもつ。

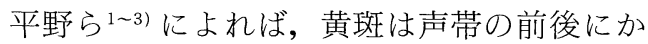
かる力のショックアブソーバーとして働くとさ れるが，その役割についてはいまだ不明な点も 多い。

一般に組織の形態から機能を明らかにするに は，全体を構成する個々の成分の形態，機能よ り全体の機能を推察する方法が有用である。 
黄斑は主に線維芽細胞，膠原線維さらに弾性 線維からなる。細胞成分は膠原線維, 弾性線維 の産生にあずかり,膠原線維は組織の形態保持, 弾性線維は加えられた力に対する復元力とい う，それぞれ別の機能を有する。黄斑の声帯振 動における意義, 機能を解明するには, 特に黄 斑を構成する成分である膠原線維と弾性線維の それぞれを観察し，その走行抢上び，その周囲 組織との関係を詳細に検討する必要がある。し かし通常の観察法では, 膠原線維と弾性線維が 混在し，また線維間に細胞成分や細胞間基質が 存在するため,それぞれの状態を把握しにくい。 そこで今回われわれは, 膠原線維と弾性線維の うち，一方と細胞を消化し，他方を観察する方 法4をとつた。つまり膠原線維の観察のために, 水酸化ナトリウムによる消化処理5,6) , 弾性線 維の観察には蟻酸による消化処理7をを行った。 そして主に走査型電子顕微鏡下にて観察した。

\section{II . 研究材料および方法}

ホルマリン固定液中に長期間保存されていた ヒト正常喉頭 8 例より得られた声带を, 長軸方 向および横軸方向に切断した。一部は $2.5 \%$ グル タールアルデヒド固定後， $10 \%$ 水酸化ナトリウ ムにて 5へ7 日間処理し，細胞成分と弾性線維 を消化した。一部は $3 \%$ パラホルムアルデヒド 固定後，90\%蟻酸にて $3 \sim 5$ 日間処理し，細胞 成分と膠原線維を消化した。つづいて標本を 1 \%タンニン酸処理後，1％オスミウム酸にて後 固定し, 洗浄, 脱水後, 臨界点乾燥, 白金の蒸 着を行い，走査型電子顕微鏡（日立 S-4100）に て観察した。一部の標本はパラフィン包埋し, 切片に Elastica Van-Gieson 染色を行い光学 顕微鏡下に観察した。

\section{III. 結 果}

以下の写真では，左方は甲状軟骨方向，右方 は披裂軟骨方向，上方は粘膜上皮方向を示す。

\section{1. 前黄斑}

図 1 に，水酸化ナトリウム処理にて弾性線維 を消化した前黄斑部を示す。比較的細い膠原線 維が密にからみあい，塊状をなしていた。

前黄斑と甲状軟骨の間は，やや細めで無方向 性, 比較的疎な膠原線維が存在し，それを介し

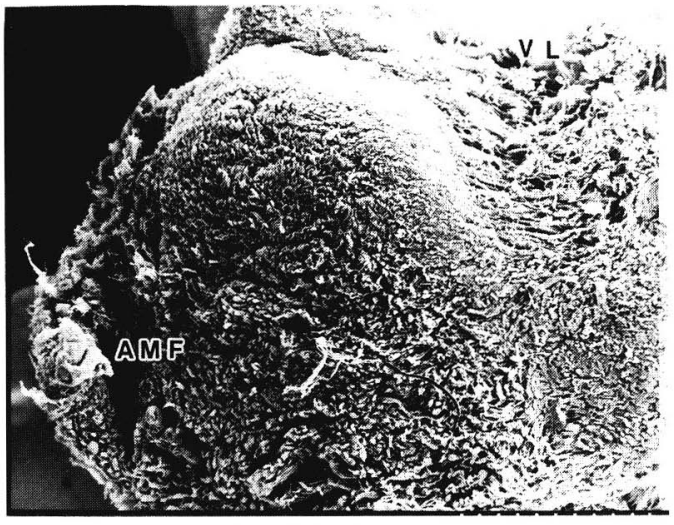

図 1 前黄斑, 膠原線維 $(\times 25)$

細い膠原線維が，塊状の前黄斑 (AMF) をなす。後 方は声帯靸帯（VL）に移行する。

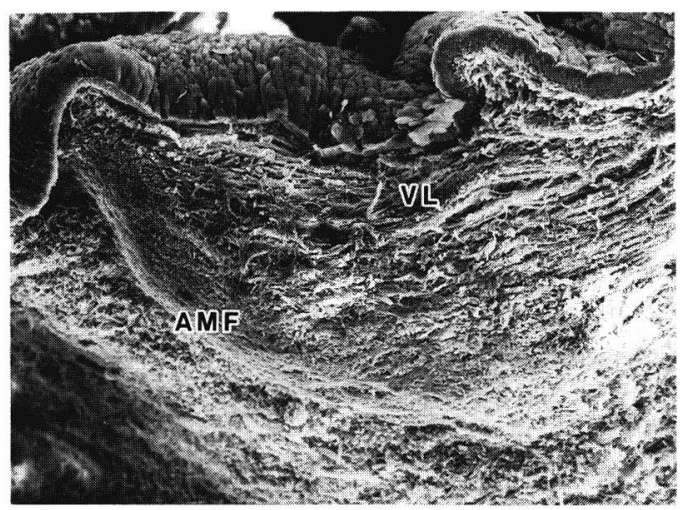

図 2 前黄斑, 弾性線維 $(\times 60)$

甲状軟骨より離れて, 弾性線維が塊状の前黄斑 (AMF) をなす。

\section{て甲状軟骨に接合していた。}

また後方は声帯勒带（粘膜固有層中間層・深 層）の長軸方向に走行する太い線維に移行して いた。

図 2 に蟻酸処理にて膠原線維を消化した前黄 斑部を示す。甲状軟骨からやや離れたところで， 細い弾性線維が無方向性に密に走行し, さらに より細い線維が分岐し互いにからみあい，塊状 をなしていた。前方の甲状軟骨との間には，比 較的細い弾性線維が無方向性で疎に分布してい た。

図 3 に前黄斑後端部の強拡大写真を示す。後 方の声带靭帯の長軸方向に走行する太い弾性線 維束は前黄斑の塊状の弾性線維の中にくい込み 


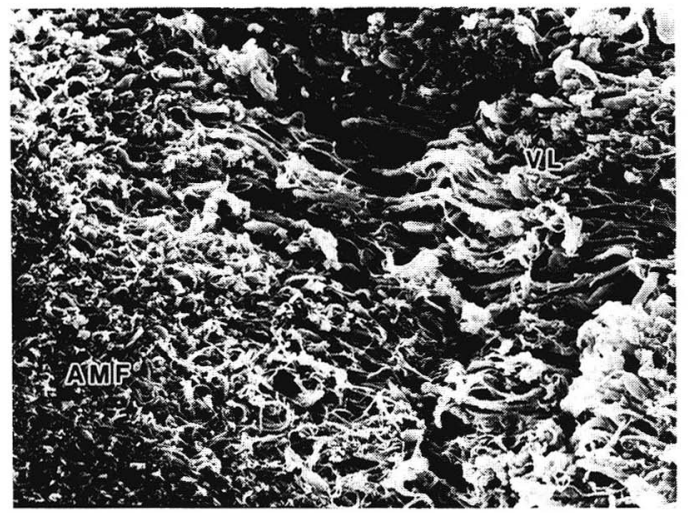

図 3.前黄斑後端部, 弾性線維 $(\times 250)$

声帯勒帯(VL)の太い弾性線維束は，前黄斑(AMF) にしっかり結合する。

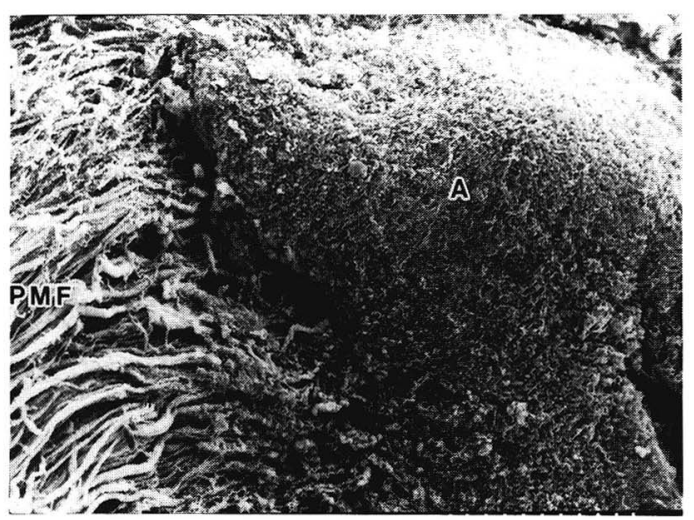

図 4 後黄斑, 膠原線維 $(\times 100)$

後黄斑（PMF）は，披裂軟骨（A）に直結する太い 膠原線維束よりなる。

\section{しっかり結合していた。}

\section{2 . 後黄斑}

図 4 に水酸化ナトリウム処理にて弾性線維を 消化した後黄斑部を示す。太い膠原線維が長軸 方向に走行し披裂軟骨に直結していた。

図 5 に蟻酸処理にて膠原線維を消化した後黄 斑部を示す。声帯勒帯の長軸方向に走行する太 い弾性線維束は，その束の太さ，密度をさらに 増しながら長軸方向の走行をつづけ披裂軟骨に 至っていた。

図 6 に，披裂軟骨接合部の強拡大を示す。後 黄斑をなす太い弾性線維束は，披裂軟骨声帯突 起の細い弾性線維塊の中にくい込み, 強く結合 していた。

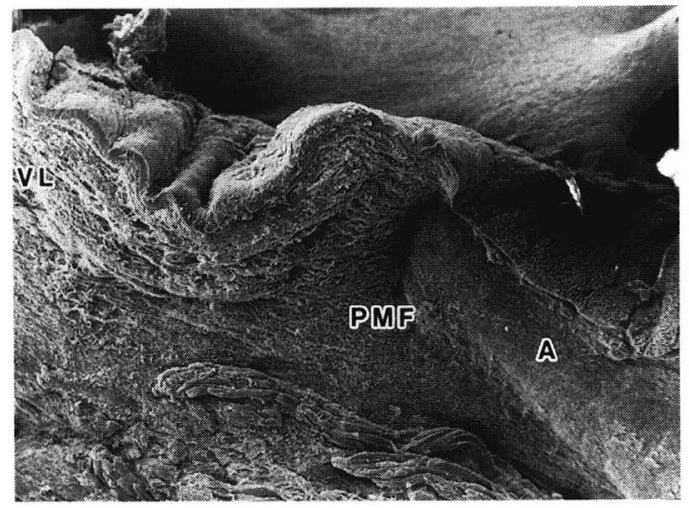

図 5 後黄斑, 弾性線維 $(\times 25)$

声帯靶帯 (VL) の太い弾性線維束は後黄斑 (PMF) で，その太さ・密度を增し，披裂軟骨（A）に至る。

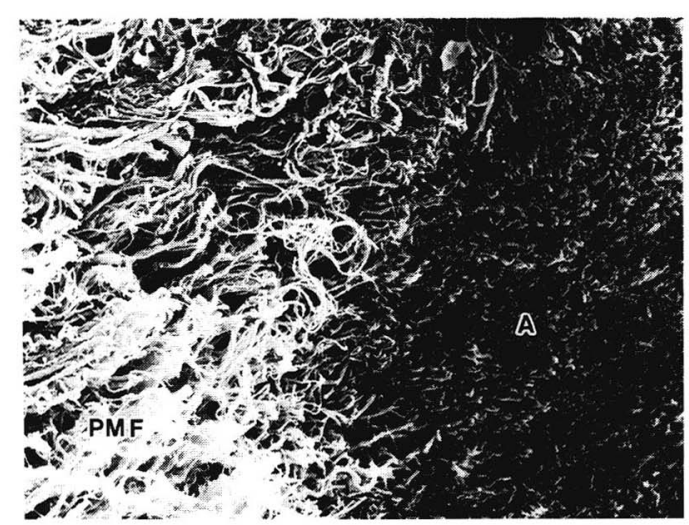

図 6 後黄斑後端部, 弾性線維 $(\times 250)$

後黄斑 (PMF) をなす太い弾性線維束は，披裂軟骨 (A)にしっかり結合する。

以上の所見は，過不足なく消化処理の行われ た標本のほぼ全例で観察された。

\section{IV. 考察}

ヒト声帯の構造については，物理的特性と調 節機構の異なるいくつかの層よりなるという層 構造の概念が確立されている1”。一方，ヒ卜声带

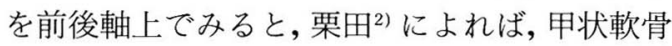
正中後面に膠原線維の密な組織を認め, その後 方に前黄斑を介して声帯膜様部がつづき，披裂 軟骨の前で前黄斑と類似した後黄斑を介して披 裂軟骨へつづくとされる。そして平野1) 抒よび 栗田 ${ }^{2)}$ は, 前および後黄斑は, 声帯の両端に機械 的損傷が加わり難いようにする緩衝的働きを有 
すると述べている。

すでに石井 ${ }^{8)}$ は，水酸化ナトリウムおよび蟻 酸処理による消化を行ったヒト声帯中央部を, 走査型電子顕微鏡にて観察し, 膠原線維および 弾性線維の詳細な構造を報告している。今回, 黄斑部においても，水酸化ナトリウムおよび蟻 酸で, 適切な日数による消化処理にて膠原線維 および弾性線維をそれぞれ単独で観察すること が可能であった。

得られた所見をまとめると次のようになる。

前黄斑は甲状軟骨からやや離れた部位に, 細 い弾性線維, 膠原線維が密にからみあい声帯䩲 帯（粘膜固有層中間層・深層）の走行とは全く 異なる塊状の構造を形成していた。また甲状軟 骨との間は疎な線維で結合され，後方は声带靱 帯の長軸方向の線維に移行していた。

後黄斑では, 声帯䩲帯中間層の長軸方向の膠 原線維は，その走行を続けたままその太さを増 して披裂軟骨に至っていた。また弾性線維は分 岐し，その密度また束の太さを増し披裂軟骨に 強く結合していた。

このように，前黄斑と後黄斑はかなり異なっ た線維構造をもつといえる。

まず, 声帯䩲帯の長軸方向の線維は, 後方で は披裂軟骨に終っているのに対して，前方では 甲状軟骨より少し離れた前黄斑に終っている。

次に, 後黄斑は声帯䩲帯の長軸方向の走行を続 けているのに対して, 前黄斑は鞀帯の走行とは 全く異なる塊状の構造をなしている。

以上のような形態から，前・後黄斑の機能を 推察した。

声帯靱帯の弾性線維は, 前筋および声帯筋の 収縮による声帯の変形から, 弛緩時速やかに復 元させる働きを持つと考えられる。また膠原線 維は, 声帯長軸方向の強い力に抵抗し, 粘膜と 声帯筋を一体化させ声帯の形態を保っていると 考えられる。

このように声帯勒帯の前後には, 長軸方向の 力に対応するしっかりとした支点が必要であ り, 前・後黄斑はその支点になっていると考え られる。

しかし前後でその構造, 働き方は異なると考 えられる。

後黄斑部は, 声帯の中で最も可動性の強い部
分であり, 後黄斑の声帯靱帯の線維が太さを増 し，しっかり披裂軟骨に結合する構造は，披裂 軟骨前端にかかる強い力に対応するものと考え られる。

一方, 前黄斑部は, 甲状軟骨から離れた状態 で，声帯䩗帯のしっかりとした支点をつくるた めに, 声帯䩚帯では別々に走行していた膠原線 維と弾性線維がからみあう塊状の構造をとるの ではないかと考えられる。

前黄斑は一部甲状軟骨に連なる部分もある が，その機能を考える場合，甲状軟骨よりむし ろその大部分が離れていることが重要であると 思われる。

前黄斑が甲状軟骨より離れている理由につい てのわれわれの推論は, 発声時の敏速なピッチ 調節には，前筋収縮による変形からの弾性線維 による迅速な回復が必要であり, 前黄斑が甲状 軟骨より離れ，その間に疎な結合織が介在する 構造は, この回復の際, 甲状軟骨の重量負荷が かかりにくくなり有利であるとも考えられる。

前および後黄斑を, 甲状軟骨, 声帯䩲带, 披 裂軟骨の連なりの中でみると, 前黄斑は声帯䩔 帯とは全く異なる塊状の構造をもつが, 後黄斑 は基本的構造は声帯勒帯の延長である。前黄斑 とその前方の結合組織は, 甲状軟骨と䩲帯の連 結部分となっているのに対し, 後方の声帯䩲帯 と披裂軟骨の連結は, 後黄斑というよりもむし ろ声帯突起と考えることができる。

甲状軟骨扔よび声帯突起以外の披裂軟骨が硝 子軟骨であるのに対し, 声帯突起は弾性軟骨で あり, フレームワークとは違った, 声帯鞀帯と 披裂軟骨の連結部として分化したものではない かと思われる。

前黄斑の膠原線維と弾性線維がからみあう塊 状の構造は, 軟骨組織ではないが, 後黄斑より もむしろ声帯突起に類似しているともいえる。 このことから, 前黄斑は, 甲状軟骨と声帯䩲帯 の連結部として, 発声のメカニズムに都合の良 いように甲状軟骨から離れて存在するようにな ったのではないかと考えることもできる。

一方, 栗田 ${ }^{21}$ は, 小児期黄斑は, 線維芽細胞に 富み, 黄斑部より声帯靱帯の線維が産生される と述べている。今回得られた所見をふまえて, 今後小児声帯の黄斑についても消化法による観 
察を行い，黄斑構造およびその声带䩚带との関 係の年齢的変化に関し検討を加えていく予定で ある。

前および後黄斑は弾性線維を多く含み，肉眼 的に黄色く見えることからそう呼ばれ，一見同 様の組織とみなされやすいものであるが，今回 の観察結果のように，その線維構造は全く異な ることが確認された。

\section{V. 結 語}

1) 前抢よび後黄斑は，ともに声帯靱帯の前 後の支点となっているが，その線維構造はきわ めて異なっていた。

2 ）後黄斑は, 可動性の最も強い部分であり, 披裂軟骨前端に直接結合し，強い力に対応して いると考えられた。

3 ）前黄斑は，甲状軟骨より離れた状態で支 点をつくるために, 声帯䩲帯ではたがいに離れ て走行していた膠原線維と弾性線維は, 密にか らみあい塊状の構造を持つと考えられた。

稿を終えるにあたり，適切な御助言を戴きました 横浜船員保険病院院長澤島政行東大名誉教授, 北里 大学医療衛生学部言語聴覚療法学廣瀬肇教授に深謝 いたします。
本論文の要旨は第47回日本気管食道科学会総会 （1995年，名古屋）において発表した。

\section{文献}

1 ）平野 実：音声外科の基礎と臨床．耳鼻，21： 239-440, 1975

2 ) 栗田茂二朗: 人声帯の層構造一形態学的研究 一。耳鼻, 26：973-997, 1980.

3 ) 平野 実, 栗田茂二朗, 藤 雄一：声带の成長, 発達と老化一とくに声帯粘膜の変化について 一。耳鼻臨床，74：1791-1802, 1981

4 ）牛木辰男：結合組織成分の走査電顕観察法. 細 胞, $22 ： 10-14,1990$.

5 ) Ohtani, O.: Three-dimensional organization of the connective tissue fibers of the human pancreas. A scanning electron microscopic study of $\mathrm{NaOH}$ treated tissue. Arch. Histol. Jpn., $50: 557-566,1987$.

6 ) Ushiki, T., and Ide, C.: Three dimensional organization of the collagen fibrils in the rat sciatic nerve as revealed by transmission and scanning electron microscope. Cell Tissue Res., $260: 175-184,1990$.

7 ) Wasano, K., and Yamamoto, T. : Tridimensional architecture of elastic tissue in the rat aorta and femoral artery-A.scanning electron microscope study. J. Electron Microsc., $32: 33-44,1983$.

8 ）石井甲介：声帯粘膜固有層の微細構造. 喉頭, $7: 87-91,1995$. 